\title{
Anistia e crise política no Brasil pós-1964
}

\author{
Renato Lemos
}

"Consultai as tradiçôes desta medida entre nós. Alvo sempre dos mais vivos antagonismos reacionários e dos prognósticos mais funestos, a anistia não recorda, todavia, na história da

República, senão benefícios à ordem e à consolidação do regime, a que ela tem servido largamente, extinguindo a discórdia, desasselvajando os partidos, restabelecendo a lei, a autoridade, a disciplina, o sossego na família brasileira. (...) É o remédio final para o abonaçamento das paixões, para a reaquisição de simpatias perdidas, para a normalização da ordem pela confiança entre governados e governantes". ${ }^{1}$

"Anistia não é esquecimento! Em primeiro lugar, porque não é possivel esquecer os episódios da grande luta em que, em plena ditadura, se engajaram centenas de milhares de brasileiras e brasileiros, exigindo justiça para as vitimas do autoritarismo e do terror de Estado. Em segundo lugar, porque a concepção de anistia que permeou a campanha e que continua a nortear a atuação dos seus militantes, nunca foi a do perdão, menos ainda a do esquecimento. Ao contrário, a tônica dos pronunciamentos e dos panfletos da campanha sempre foi a denúncia dos crimes da ditadura, exigindo o esclarecimento das mortes e dos 'desaparecimentos', com a devida responsabilização dos culpados (...)". ${ }^{2}$

\section{Lição introdutória}

E mbora não constitua um tema muito freqüentado pelo pensamento nários de poder. Recentemente, ela foi apontada como solução para grave crise institucional vivida na Venezuela.

A ascensão do coronel da reserva Hugo Chávez ao poder constitucional naquele país preparou uma armadilha para o pensamento democrático 
nas Américas. Em 1992 ele havia tentado depor o presidente Carlos Andrés Peres, a quem acusava de corrupto. Fracassou, mas Peres acabou sendo objeto de impeachment. Preso, Chávez foi anistiado em 1994. Classificado como populista pelos adversários, elegeu-se presidente da República em 1998 e 2000. Em abril de 2002, foi derrubado por uma coalizão golpista que reunia empresários, militares e segmentos da classe média venezuelana. Dois dias depois, retornou ao poder, graças a um contragolpe desferido por seus partidários em aliança com militares legalistas.

Que os dirigentes das democracias americanas não vêem com bons olhos a presença de Chávez no poder não chega a ser novidade para qualquer cidadão medianamente informado. O que talvez não seja tão evidente é a crua face pragmática de nossos democratas diante das turbulências por que tem passado a terra natal de Simon Bolívar.

Entre nós, a reação imediata do presidente Fernando Henrique Cardoso ao golpe contra Chávez é rica de sugestôes a este respeito. A televisão o mostrou sacando as armas do arsenal da teoria democrática: o continente não comporta mais rupturas institucionais, por isso é necessário que se realizem eleições no mais breve prazo, afirmou. Como postulante à condição de líder continental, o presidente não poderia ter explicitado de maneira mais eficaz os limites do pensamento democrático atual: embora se tratasse da derrubada de um presidente democraticamente eleito, não exigiu a imediata recondução de Chávez ao poder. Ao contrário, pediu providências — eleições — que legitimassem a nova situação — o poder dos golpistas! Esta posição passou praticamente despercebida da opinião pública brasileira.

Surpreendido pelo contragolpe de Chávez, o presidente Fernando Henrique, que, como se sabe, é professor aposentado, mudou de posição em face da crise venezuelana e aproveitou para dar liçóes de democracia ao militar populista em apuros. O tema escolhido foi a anistia. Ensinou a Chávez que o presidente Juscelino Kubitschek (1956-1960) foi vítima de duas tentativas golpistas por parte de oficiais da Aeronáutica, com focos em Jacareacanga (1956) e Aragarças (1959). E que, num gesto de reconciliação, tomou a iniciativa de anistiar os revoltosos. ${ }^{4}$

Um imaginário plano didático indicaria que o objetivo da aula era fazer com que Chávez seguisse o exemplo de Kubitschek, já que a anistia teria 
contribuído para o alto grau de estabilidade política conseguido em seu governo, evidenciado pelo fato de ter sido o único presidente civil do período 1945-1964 a exercer integralmente o mandato. A aula, porém, limitou-se ao exemplo, deixando de lado importantes aspectos históricos e políticos relacionados à anistia. $\mathrm{O}$ objetivo destas notas é apresentar como tais aspectos estão sendo analisados na pesquisa "Anistia e crise política no Brasil, 1964-1979", em curso no Laboratório de Estudos sobre os Militares na Política, sob minha coordenação e em parceria com Cristina de Andrade Luna e Flávia Burlamaqui Machado, alunas do curso de graduação em História.

\section{Sobre a tradição brasileira de anistia política}

O Brasil tem uma já considerável tradição no campo da anistia política. ${ }^{5}$ Mas, há diferenças de situações que implicam significados políticos diversos e devem ser observadas. Ao longo da nossa história, tanto foram anistiadas pessoas acusadas de atentar contra a legalidade ilegitimamente estabelecida - as que se insurgiram contra as ditaduras do Estado Novo e do regime militar recente, por exemplo - , como as que tentaram subverter a legalidade legitimamente estabelecida, de acordo com os parâmetros democráticos dominantes — os golpistas de 1956 e 1959, por exemplo. Desconsiderar este ponto faz com que não se perceba que a tradição brasileira em matéria de anistia política expressa também duas outras tradições, mais abrangentes: a da conciliação como forma de preservação dos interesses fundamentais das classes dominantes na nossa sociedade e a da contra-revolução preventiva como estratégia anticrises.

José Honório Rodrigues, um historiador atualmente um tanto fora de moda nos meios acadêmicos, dedicou boa parte de sua energia intelectual a denunciar o caráter contra-revolucionário da prática conciliatória das elites políticas brasileiras. Para ele, a "política de conciliação" é sempre a "conciliação das divergências da minoria dominadora", seu objetivo principal é mais contornar as contradiçôes entre os grupos dominantes que "conceder benefícios ao povo" e, embora sempre se fale "em pacificação, confraternização", a ordem é o seu alvo. ${ }^{6}$ 
Sangrentos dissídios sempre deram margem à expansão do tal "espírito de reconciliação" que o presidente Fernando Henrique tentou inocular em Chávez, mas, diante dele, alguns dissidentes têm sido considerados mais merecedores de "reconciliação" do que outros. Basta que se observe como aqueles que tinham o poder de reconciliar trataram os "menos iguais" os balaios, os praieiros, os marujos de 1910 — e, por outro lado, as deferências com que cumularam os "mais iguais", como os liberais mineiros e paulistas de 1842 e os farrapos.

A atitude conciliadora subentende, em geral, uma pretensão à harmonia conservadora: motivos, conduta e propósitos "tidos como correlativos 'sensatos' da idade madura, de equilíbrio temperamental ou psicológico, ou do interesse adquirido - ou de uma combinação destes fatores ligados a geração, personalidade e posição". ${ }^{7}$ Arno Mayer observa que este conservadorismo ideológico costuma ser eficiente na defesa da ordem em tempos normais, mas em tempos de crise sente-se fraco e menos autoconfiante: "Quando a política de conciliação e acomodação perde terreno, os conservadores buscam outros métodos mais eficazes". Um deles é, com freqüência, a contra-revolução. ${ }^{8}$

As idéias de contra-revolução, formuladas por pensadores como Burke, Maurras e Bonald, ${ }^{9}$ surgiram a compasso com a Revolução Francesa. Inicialmente, dirigiram-se contra a burguesia revolucionária, em defesa dos interesses feudais e clericais. Ao longo do tempo, contudo, a teoria da contra-revoluçãao

sofre uma importante transformação em sua função: ela é finalmente adaptada pelas camadas dominantes da burguesia. A burguesia passa de objeto a sujeito da teoria. Ela representa, para a época, o exemplo mais notável de justificação e defesa de uma ordem social ameaçada. A mudança de função da teoria acompanha a história da burguesia a partir da luta de uma classe em ascensão contra os restos de uma organização social que se transformou em obstáculo até a dominação absoluta de algumas camadas privilegiadas contra o ataque de todas as forças progressistas; ela acompanha também a rejeição por essa burguesia de todos os valores que havia proclamado na época de sua ascensão. ${ }^{10}$

É crucial, portanto, situar o fenômeno da contra-revolução na tendência a crises apresentada pelo mundo europeu pós-Revolução. Deste 
ponto de vista, trata-se de um fenômeno estrutural de sociedades em que a sucessão de crises em intervalos progressivamente mais curtos agrava suas condições e dificulta práticas acomodatícias. A contra-revolução, observa Arno J. Mayer, ${ }^{11}$

não é um fenômeno de equilíbrio político e econômico ou social. Não surge em sociedades estacionárias e estáveis. Na realidade, a contra-revolução é um produto e um estimulante da instabilidade, das cisões e da desordem. Viceja quando as forças normalmente conflitantes porém acomodadoras começam a abandonar a política de conciliação.

Após a Revolução Russa, em 1917, a inversão de papéis mencionada por Marcuse assumiu feições mais radicais, na medida em que os processos revolucionários alastravam seu potencial de ameaça à ordem burguesa - a guerra civil internacional iniciada, a rigor, em 1917 e conhecida pelo eufemismo "Guerra Fria". ${ }^{12}$ Para Mayer, o fato histórico a ser aceito é o da revolução, a cuja historicidade se liga simbioticamente a contra-revolução. ${ }^{13}$ Esta díade indica que, no contexto histórico contemporâneo mundial,

a revolução comunista — inicialmente na sua fase russa, em seguida em sua fase chinesa - é o fato central deste período. Com isto, os demais países e por que não dizer seus vizinhos — mediam-se e continuam a medir-se por este modelo revolucionário; reagiram e continuam reagindo com atitudes repressivas internas e externas. ${ }^{14}$

O agravamento de crises econômicas e sociais no mundo tende a ativar a ameaça da revolução, como possibilidade real ou espectro. Nestas condições, os setores sociais concentradores da riqueza "dão prioridade máxima à proteção e à preservação de suas posições e bens ameaçados, se necessário através da colaboração com os contra-revolucionários". ${ }^{15}$ Tornam-se, eles mesmos, contra-revolucionários ao recorrerem à manipulação da ameaça revolucionária.

Para compreender o fenômeno contra-revolucionário, é muito mais importante discernir as mutaçôes de opiniōes e avaliações hostis sobre as potencialidades, intençôes e atos revolucionários do que reconstruir as suas realidades objetivas. Em pontos críticos, as elites dentro e fora do governo são levadas a tolerar, apoiar ou implementar as políticas contra-revolucionárias, 
quer por um temor genuíno (embora não necessariamente justificado em termos objetivos) ou por interesses de conveniência disfarçada. ${ }^{16}$

Em situações de forte mobilização de setores sociais em favor de reformas $^{17}$ ou de grave crise governamental, que aponte o risco de uma conflagração, cria-se um ambiente marcado por "suspeitas, incertezas e violência jacente". Líderes contra-revolucionários são estimulados ao trabalho de convencimento das classes dominantes de que a crise é revolucionária, o confronto é questão de tempo e há que adotar a estratégia da contra-revolução preventiva. ${ }^{18}$ Assim,

em lugar de procurarem desanuviar essa atmosfera carregada, fazem o possível para inflamá-la ainda mais. Com isto, pretendem reforçar a sua afirmação de que a revolução é iminente, ao mesmo tempo em que desejam, ou até precipitam confrontos onde possam demonstrar sua capacidade de derrotar os revolucionários reais ou imaginários. Evocando o risco que correriam caso dessem tempo para que os revolucionários preparassem seus recursos e planos para um ataque segundo os seus próprios termos, os líderes contra-revolucionários reivindicam uma ação preventiva. ${ }^{19}$

Deste ponto de vista, a anistia pode ser entendida como um instrumento da contra-revolução preventiva no contexto de crises políticas que anunciam sua gravidade real ou potencial. Trotsky alude a uma modalidade democrática da contra-revolução burguesa, constante do repertório de respostas possíveis a ameaças à ordem oriundas do movimento político revolucionário de operários e camponeses. ${ }^{20}$ Exatamente porque sempre satisfaz legitimamente uma parcela considerável da oposição, ${ }^{21}$ a concessão da anistia facilita ao bloco dominante dividir o campo dos contestadores. Enfraquecendo desta maneira a frente oposicionista, viabiliza também a reunificação dos setores divergentes do bloco dominante em torno de seus interesses fundamentais, de maneira a garantir o essencial da ordem. $\mathrm{O}$ resultado deste tipo de estratégia costuma ser a limitação do confronto de posições, um obstáculo a que se tome pela raiz o problema que gera a crise, cujos elementos assim tendem a se aprofundar. Esta "habilidade" sempre distinguiu a vida política brasileira no quadro latino-americano. $\mathrm{O}$ presidente Fernando Henrique Cardoso parece ter pretendido exportar este patrimônio nacional para a Venezuela. 


\section{Sobre a anistia de 1979}

A anistia de 1979 resultou de uma grande transação entre setores moderados do regime militar e da oposição, por iniciativa e sob o controle dos primeiros. Integrou a agenda de microtransformações, ${ }^{22}$ buscadas desde 1973 por lideranças militares e civis do governo: ampliação do leque de opções partidárias, abrandamento da legislação repressiva etc. Tratava-se de preparar a transição do regime, não necessariamente para outro qualitativamente diferente, mas para outra forma, que incorporasse novas forças políticas, sem descartar a tutela militar. Os limites das reformas foram dados, desde logo, pelo caráter estritamente burguês da direção do processo político. O sentido básico da transição foi preservar as condições da dominação política de uma classe social absolutamente desprovida de vocação transformadora. Pode-se dizer da burguesia brasileira o que Trotsky disse da espanhola na década de 1930. Constituída hipertardiamente no panorama do capitalismo mundial, ela é dependente do capital estrangeiro até a medula dos ossos e "está aderida como um vampiro ao corpo do povo". ${ }^{23}$

A negociação da anistia implicou o confronto entre os diversos projetos políticos voltados para a conjuntura de transição vivida pelo país. ${ }^{24}$ Desde que, ao assumir a Presidência da República em 15 de março de 1974, o general Ernesto Geisel anunciou um programa de "abertura lenta, gradual e segura”, o processo político nacional passou a ser polarizado pela agenda da transição de regime. ${ }^{25}$ Os anos que se seguiram foram marcados por retumbante vitória da oposição democrática nas eleições legislativas de 1974 e pelo crescimento das manifestações de setores da sociedade em favor da redemocratização do país, como o surgimento do Movimento Feminino pela Anistia, em 1975, e do Comitê Brasileiro pela Anistia (CBA), em 1978. Ao final de seu governo, haviam sido dados alguns passos importantes no sentido do abrandamento das formas de dominação política, destacadamente a revogação dos atos institucionais e reforma da Lei de Segurança Nacional.

Neste quadro, a oposição militar de direita não via com bons olhos a agenda da abertura, inclusive a anistia, pelo menos no ritmo e na abrangência com que era encaminhada durante os governos dos generais Geisel e João Figueiredo (1979-1985). ${ }^{26}$ Retorno de políticos cassados, interrup- 
ção de processos em andamento na Justiça Militar etc. eram desdobramentos da anistia que despertavam resistências na linha dura militar. ${ }^{27}$

A oposição à esquerda exigia uma "anistia ampla, geral e irrestrita" (bandeira do CBA), acompanhada da apuração dos crimes praticados por funcionários do Estado contra opositores políticos e punição dos culpados. Na guerra pela memória da anistia, surgem indícios, no entanto, de que setores oposicionistas tinham uma proposta mais limitada. Dois políticos com importante participação na articulação da medida — Jarbas Passarinho, senador pelo Pará, e Tales Ramalho, então secretário-geral do Movimento Democrático Brasileiro (MDB) — afirmaram, vinte anos depois, que um substitutivo elaborado por destacados emedebistas era menos abrangente do que o do governo:

Correram rumores da existência de manobra de Ulysses Guimarães para impedir que, anistiados os líderes no exílio, viessem a dominar a oposição em detrimento dos que haviam lutado, anos a fio no Brasil, contra o regime autoritário. Os rumores são agora confirmados pelo doutor Tales Ramalho, em entrevista à imprensa, ${ }^{28}$ há poucos dias, declarou textualmente: "A anistia imaginada pelo MDB excluía os líderes oposicionistas Leonel Brizola e Miguel Arraes. ${ }^{29}$

Segundo Passarinho, a própria agenda da abertura livrava o governo de receios em relação ao retorno dos líderes populares derrotados em 1964. A anistia se combinaria com o restabelecimento do pluralismo partidário, com o objetivo de fracionar o MDB, que, de partido da oposição consentida, se tornara desaguadouro eleitoral do descontentamento com o regime. ${ }^{30}$

A inteligência estava em se saber claramente que era muito pouco provável que Prestes e Brizola se unissem. A partir do momento que os rios fossem independentes, o nosso continuaria maior. A Arena [Aliança Renovadora Nacional, partido de sustentação da ditadura militar] continuaria preponderante, comparada com as facções. ${ }^{31}$

Por isso, o general Golbery do Couto e Silva, chefe do Gabinete Civil da Presidência da República, e Petrônio Portela, ministro da Justiça desde janeiro de 1979, teriam incluído nos benefícios do projeto do governo os 
punidos por motivos políticos desde setembro de 1961 ("Crise da Legalidade"). O projeto foi entendido por parte da oposição como uma operação de esvaziamento da mobilização pela anistia, assim como a reforma partidária visaria enfraquecer a oposição pelo seu fracionamento. Integrantes do governo do general Figueiredo asseguram, no entanto, que a concessão da anistia fizera parte das negociações que resultaram na sua indicação à sucessão presidencial e fora anunciada logo após a sua posse, quando, referindo-se aos oposicionistas exilados, proclamou: "lugar de brasileiro é no Brasil". ${ }^{32}$ Entretanto, a lei aprovada em 28 de agosto de 1979 teve alcance restrito, excluindo de seus benefícios os condenados pela "prática de crimes de terrorismo, assalto, seqüestro e atentado pessoal". Por outro lado, incluía os acusados de "crimes conexos", isto é, de tortura, assassinato etc., o que dava à medida um caráter de "reciprocidade". ${ }^{33}$

Este curioso malabarismo jurídico não chega a constituir artigo de produção exclusiva brasileira e sim uma maneira de entender a administração de transições políticas adotada em várias partes do mundo. Ainda assim, a experiência brasileira foi reivindicada como matriz de soluçôes adotadas na África do Sul na fase de desmontagem do sistema de apartheid. Quem o fez foi o reverendo Desmond Tutu, um dos líderes locais na luta contra o racismo e presidente da Comissão de Reconciliação e Verdade, criada em 1995 com prazo de dois anos para investigar os casos de violência política entre 1960 e 1993 e anistiar aqueles que dessem detalhes sobre "abusos por motivos políticos" durante o apartheid e se declarassem arrependidos. Considerando que a comissão contribuía efetivamente para a reconciliação do país, ${ }^{34}$ Tutu declarou ao presidente Fernando Henrique Cardoso, que visitava a África do Sul: "Nós temos muito que aprender com o Brasil". 35

Mais recentemente, o parlamento russo aprovou decreto de anistia para todos os rebeldes tchetchenos que entregassem suas armas até uma data por ele fixada. A medida visava, oficialmente, acelerar o fim da guerra na Tchetchênia e guardava importantes semelhanças com a anistia brasileira de 1979: era restrita, já que não se aplicava aos comandantes tchetchenos, e recíproca, porque beneficiava os soldados russos acusados de assassinar e torturar rebeldes. ${ }^{36}$ 
No Brasil, o "espírito de reconciliação" que norteou este caráter recíproco contribuiu também para que fossem anistiados eticamente todos os que sustentaram a violenta ditadura militar. Muitos deles são, hoje, pilares da democracia brasileira, atuando em posições públicas destacadas, o que mereceu de um jornalista um comentário amargo: "No Brasil, eu precisaria de umas 50 colunas iguais a esta para listar todos os que estavam com o governo, no regime militar, e continuam com o governo, na democracia”. ${ }^{37}$

Exercem esta continuidade dando as mãos a antigos adversários. É o "espírito de reconciliação" que permite a tranqüila convivência no poder entre antigos expoentes da ditadura militar - Antônio Carlos Magalhães, José Sarney, Marco Maciel etc. — e "subversivos" dos anos 60 - entre os quais o presidente Fernando Henrique Cardoso e José Serra, seu candidato nas eleições presidenciais de outubro de 2002. Foi igualmente o "espírito de reconciliação" que obstou a apuração de crimes de tortura e assassinato praticados por membros dos serviços de segurança e acobertados pelos governos militares. Foi ele, ainda, que permitiu situações como a que motivou mais um protesto do nosso indignado jornalista:

No momento em que, em boa parte da América Latina, se reabre a discussão sobre os excessos cometidos pelos governos militares da região nos anos 70/80, um dos maiores estados brasileiros [Rio de Janeiro] coloca como secretário da Segurança Pública um ex-integrante do Doi-Codi (Departamento de Operaçôes Internas/Centro de Operações de Defesa Interna). (...) O coronel Nilton Cerqueira trabalhou no braço baiano do sistema. O DoiCodi foi o principal responsável pelas torturas, mortes e demais violências praticadas no período. (...) Pode-se aceitar que a anistia apagou tais crimes, bem como os praticados pela parte oposta, que também os cometeu. Mas a anistia tem um efeito meramente jurídico. Não pode invadir o território da política. Há pessoas que se tornaram no mínimo inconvenientes para a convivência democrática, a partir do comportamento que tiveram durante o ciclo autoritário. Que tais pessoas continuem a sua vida profissional mesmo nos aparelhos de segurança do Estado, pode-se ainda tolerar, num rasgo de extrema boa vontade, em nome da tal de conciliação nacional. Mas que assumam posições de relevo, aí já é ultrapassar todos os limites. ${ }^{38}$

A sobrevivência de indivíduos e instituições é típica de transições negociadas sob liderança de forças da ordem ditatorial. A preservação de pe- 
ças estratégicas do Estado Novo (1937-1945) — a estrutura sindical e a posição de poder do general Eurico Dutra, por exemplo - na ordem democrática pós-1945 ilustra bem esta tese. Alguns analistas explicam o fenômeno como resultado de características do próprio regime ditatorial: longa duração, ausência de cultura política democrática prévia, pequena ou nula renovação das lideranças. ${ }^{39}$ É preciso, porém, considerar que as transições negociadas constituem, em geral, uma estratégia de sobrevivência das distintas fraçóes das classes dominantes. Em busca de uma forma de garantir os elementos essenciais de poder econômico e social, seus representantes acertam, tácita ou explicitamente, a presença de pessoas e instituições ligadas ao regime ditatorial na estruturação da ordem que o substituirá. Trata-se, antes de tudo, de evitar que a situação de crise política evolua no sentido da contestação revolucionária da ordem social, hipótese alimentada pelo aprofundamento das divisóes internas ao bloco no poder. A continuidade da velha na nova ordem é viabilizada pelas salvaguardas embutidas no pacto de transição estabelecido entre os setores moderados do quadro político, entre as quais a natureza restrita e recíproca da anistia.

Pela Lei $\mathrm{n}^{\circ}$ 9.140, de autoria do governo e aprovada pelo Congresso Nacional em agosto de 1995, oficializou-se a morte de pessoas "desaparecidas" por motivos políticos entre setembro de 1961 e agosto de 1979. Foi, também, estabelecida a indenização a parentes dos desaparecidos. Tudo de acordo com "o princípio de reconciliação e de pacificação nacional, expresso na Lei de Anistia”. Conseguido o efeito simbólico de reparação, a sociedade como um todo a financia, inclusive muitas pessoas que se opuseram à ditadura com sérios riscos para sua vida. Já generais-presidentes, ministros civis e militares, funcionários públicos envolvidos até a medula dos ossos com o emprego da violência contra cidadãos são, na prática, juridicamente irresponsáveis e nunca pagarão por seus crimes, graças à reciprocidade embutida na lei da anistia. ${ }^{40}$

Reaçôes a esta lei são ricas indicações dos limites da idéia de esquecimento em face de conflitos políticos muito acirrados. À direita, militares, antes mesmo que a lei fosse promulgada, protestaram contra o seu propósito. Foi o que fez o ministro do Exército, por meio de nota oficial em que se opõe a "qualquer investigação para apuração de responsabilidades" so- 
bre as mortes. Ainda na área do Exército, o general Murilo Neves Tavares da Silva, comandante da $7^{a}$ Região, pediu transferência para a reserva por discordar da indenização aos familiares, que considerava "revanchista", e foi atendido pelo ministro Zenildo de Lucena. Na Marinha, o ministro Mauro César Pereira também se manifestou contra apuração de responsabilidades pelas mortes, porque haveria "muito desaparecido que está muito bem vivo por aí (sic)", embora não citasse qualquer nome de pessoa nessa condição. ${ }^{41}$

Uma posição centrista pode ser identificada na reação de um membro militar da comissão criada pelo Ministério da Justiça, em dezembro de 1995, para efetuar o levantamento dos desaparecidos e avaliar os pedidos de indenização. De um lado, reconhecia que a lei "teve o mérito de delimitar e esclarecer a violência política no período". De outro, denunciava que "idéias esdrúxulas, em forma de pareceres que chamo de 'cabalísticos', tentam mudar o que foi elaborado pelo Congresso e sancionado pelo presidente da República”. No seu entendimento, a lei "deu asas ao revanchismo de todos aqueles que querem ver os militares de costas para a vida política nacional". Estaria em curso, na verdade, uma operação em que "revanchistas, espertamente, aproveitam-se da chaga a nós legada por uma pequena minoria que, contrariando a tradição das Forças Armadas brasileiras e sem respaldo dos chefes militares, cedeu à tentação da tortura em presos políticos, para obter resultados mais rápidos e efetivos na repressão". Exemplo desta tese seria a interpretação que concedeu indenização a parentes do guerrilheiro Carlos Lamarca, morto fora de dependências policiais num "combate de encontro" com uma patrulha em que poderia ter matado seus perseguidores se não tivesse sido surpreendido. ${ }^{42}$

À esquerda, um jurista considerou fraudulenta a lei de anistia, porque votada "sob a égide do regime que propiciou tais horrores" 43 e "destinada a absolver de antemão todos os governantes e altos funcionários envolvidos na repressão sangrenta”. ${ }^{44}$ Questionava a essência do caráter recíproco da lei de anistia, porque

não pode ser considerado anistiado de determinado crime quem nunca foi oficialmente acusado de sua prática. Ora, nenhum agente estatal do regime militar chegou a ser processado como autor de desaparecimentos forçados 
de opositores políticos, crime que os governos militares sempre negaram que tivessem sido cometido. ${ }^{45}$

Também no campo da esquerda, um deputado apontou, em pronunciamento na Câmara, a ótica distorcida do governo que em

seu discurso defendendo o esquecimento do passado e igualando a violência do Estado à resistência dos democratas revela uma concessão aos revanchistas da ditadura militar. Pelo seu discurso e pelo seu projeto, o governo sustenta a lógica do regime militar. Trata a questão dos mortos e desaparecidos como uma questão humanitária, como uma relação entre o Estado e as famílias. ${ }^{46}$

É flagrante o contraste com os rumos seguidos pelas transições políticas em outras sociedades latino-americanas em relação à cobrança de responsabilidade de funcionários do Estado acusados de crimes contra opositores políticos. No Chile, foi preso Manuel Contreras, chefe de Polícia da ditadura comandada pelo general Augusto Pinochet. Na Argentina, foi condenado o almirante Augusto Massera, membro da junta militar que governou a Argentina no período ditatorial, pelo crime de seqüestro de bebês recém-nascidos enquanto esteve no poder. É verdade que tais medidas representam momentos específicos na luta política que se trava nestes países em torno do rescaldo da ditadura. Em outros momentos, o Chile fez uma conciliação radical com Pinochet, respeitando parte de seus poderes, ${ }^{47}$ enquanto o mesmo Massera foi, antes da detenção mencionada acima, condenado, juntamente com Rafael Videla, seu companheiro de junta, à prisão perpétua e posteriormente anistiado. Ainda assim, a simples formalização da denúncia dos crimes e a subseqüente decretação de penas já indicam uma maneira menos conciliatória de lidar com a questão dos crimes cometidos por agentes do Estado durante os períodos ditatoriais.

\section{Sobre o esquecimento ou: "Amarrem uma lata ao rabo dos golpistas"}

A anistia permite que permaneçam na vida política pessoas que acabam por afinar-se com o jogo democrático, mas também outras que optam por tornar-se os seus coveiros. Nelson Werneck Sodré observa uma 
linha de continuidade dos protagonistas de tentativas de golpe após 1930, vitoriosas ou não (em 1937, 1945, 1954, 1955, 1961 e 1964), concluindo:

Basta verificar a galeria de personagens envolvidas em tais golpes para comprovar como constituem filão único, sempre com o mesmo sentido: intervir pela força militar contra o processo democrático normal, a serviço de componentes políticas a que a decisão popular, mesmo nas condições eleitorais precárias do Brasil, jamais deu assentimento. ${ }^{48}$

A lista de Sodré exclui os episódios ocorridos no governo de Juscelino Kubitschek, lembrados pelo presidente Fernando Henrique Cardoso na aula ministrada a Hugo Chávez, porque não alteraram a composição do poder. Para a discussão do problema político da anistia, no entanto, eles são emblemáticos. Os atentados contra os direitos constitucionais de Kubitschek não foram um episódio isolado. Desde a derrota do candidato da União Democrática Nacional (UDN) à Presidência da República em 1945, brigadeiro Eduardo Gomes, um setor da Aeronáutica demonstrava tendências golpistas. As revoltas de Jacareacanga (1956) e Aragarças (1959) foram debeladas pelo governo, mas a anistia aos golpistas, em vez de trazer e garantir a pacificação, estimulou o prosseguimento das articulações subversivas.

Veja-se o caso de dois dos principais líderes dos dois movimentos. ${ }^{49}$ O major-aviador Haroldo Veloso, derrotado em Jacareacanga, foi preso, anistiado, promovido a tenente-coronel-aviador e reincidiu no golpismo, participando da revolta de Aragarças. Chegou ao topo da carreira e, depois do movimento político-militar de 1964, efetuou vôos rasantes sobre o palácio do governo de Goiás, ato de coação contra o governador Mauro Borges, que acabaria tendo o seu mandato cassado. Posteriormente, elegeu-se deputado federal pelo Pará na legenda da Aliança Renovadora Nacional (Arena), partido situacionista durante o regime militar. Seu reduto eleitoral: a região em torno de Jacareacanga e Aragarças!

Já o então tenente-coronel João Paulo Burnier, principal chefe do movimento de Aragarças, não se beneficiou de anistia, porque, quando a medida foi decretada no governo de João Goulart, ele, que inicialmente se refugiara na Bolívia, já havia retornado ao Brasil sem que lhe cobrassem pelo ato ilegal. No gozo da total impunidade, conspirou contra Goulart e, 
no dia do golpe que o depôs, praticou atos de sabotagem, como a instalação de cargas de dinamite no Palácio Guanabara, sede do governo carioca, supostamente para impedir que o prédio fosse tomado pelos comunistas. Durante o regime militar foi promovido a brigadeiro-do-ar e acusado de mentor intelectual de atos terroristas (caso Para-Sar) e de responsabilidade por torturas na III Zona Aérea, sob seu comando em 1971.

A iniciativa de Kubitschek no sentido de anistiar os golpistas certamente terá contribuído para apaziguá-los e, na medida do seu potencial desestabilizador, garantiu tranqüilidade ao governo. Entretanto, não assegurou que eles incorporassem o espírito da palavra, nem impediu que se gestasse o ovo da serpente.

O vocábulo anistia tem sentidos comuns, tanto no vocabulário jurídico especializado quanto no linguajar leigo: um ato de perdão que torna inexistente uma atitude anteriormente considerada negativa. Etimologicamente, anistia significa esquecimento. No plano pessoal, podemos esquecer algo de ruim que nos tenha sido feito e estabelecer relações harmônicas com seu autor. No plano administrativo, devedores de tributos podem ter seus débitos zerados como forma de estímulo ao cumprimento regular de compromissos futuros. Em ambos os casos, há uma opção pelo esquecimento.

A decretação da anistia torna inexistente a natureza criminosa atribuída a um ato determinado. Evidencia-se, assim, a natureza contratual — contrato estabelecido entre iguais e imposto aos inferiorizados — da ordem jurídica. Alguns autores deduzem daí a natureza de "ficção jurídica" da anistia, ${ }^{50}$ cuja adoção decorre das "conveniências políticas do legislador". Desta natureza política resulta que a anistia pode ser discutida politicamente. A sua finalidade é definida em termos de pacificação da sociedade pela via do esquecimento:

Num certo momento mostra-se mais conveniente perdoar, esquecer, supor que os crimes de então jamais existiram do que perseverar na imposição de sanções aos seus autores quando, na maioria das vezes, as circunstâncias que ensejaram a prática daqueles atos não mais remanescem. É fácil entender que, alteradas as circunstâncias políticas que determinaram a punição, cesse também a ação do Estado contra os rebeldes. ${ }^{51}$ 
A questão que se coloca é: e quando as circunstâncias não mudaram e a anistia é decretada mesmo assim? Não se está contribuindo para a reprodução do ato ilegal? Voltando ao caso dos golpistas da Aeronáutica, caberia indagar: teria Kubitschek perguntado a eles se estavam dispostos a "esquecer" seus propósitos criminosos?

Por outro lado, sendo medida de conveniência política, nem sempre a anistia tem o propósito do perdão. A anistia concedida em 1910 aos revoltosos da Marinha brasileira ainda de armas na mão, durante o episódio conhecido por Revolta da Chibata, provocou grande discussão em vários setores da sociedade. $\mathrm{O}$ ato foi considerado por muitos como demonstração de fraqueza do governo e desagradou aos chefes militares, que se sentiram desprestigiados. No Senado e na Câmara a medida foi aprovada rapidamente, mas, depois, os principais membros do governo tentaram isentar-se de responsabilidade pelo projeto, que fora apresentado por Rui Barbosa, então líder da oposição, a pedido de um senador situacionista. Rui explica por que defendeu a medida:

Defendi a anistia porque o Sr. Senador Severino Vieira me disse que o Governo a queria, que o governo sem ela não podia passar. Defendi a anistia porque eu a considerava como justa. Defendi a anistia porque, tendo eu posto o seu dilema, o Senado não me respondeu se o Governo podia vencer. Defendi a anistia porque, sustentando eu que $o$ Governo não tinha meios de se defender, todo o Senado concordou comigo. Defendi a anistia, porque esperava que o presidente da República por ela se empenhasse. Defendi a anistia, porque não sabia que a Marinha lhe fosse contrária. Defendi a anistia, porque não imaginava que o ministro da Marinha lhe fosse avesso. Defendi a anistia porque estava longe de pensar que o chefe da Armada não tivesse sido ouvido. Defendi a anistia, porque não sabia, como hoje me consta, que as autoridades militares consideravam exeqüivel a vitória, num ataque noturno contra os navios revoltados. Eis por que defendi a anistia. ${ }^{52}$

Ainda sob o impacto do golpe de 1964 e da orientação do regime militar em seu primeiro ano de vigência, um escritor, por outros motivos, negou à anistia que reivindicava o sentido de perdão:

Ninguém está pedindo perdão a este governo. Tal pedido implicaria o reconhecimento de culpa. O que se pede, o que se exige é que, pela ausência de provas provadas, por não ter o Executivo capacidade de presidir a processos 
regulares, nem ter moral para condenar ninguém, conceda o Congresso a anistia total, sem restrições, sem barganha. ${ }^{53}$

De ambas as argumentações infere-se que a anistia, como qualquer medida política, é uma questão de correlação de forças. ${ }^{54}$ No interior das Forças Armadas, principal ator político durante a ditadura militar, a questão da anistia durante muito tempo apontou para os conflitos entre as correntes em que os oficiais se dividiam. Um ponto essencial era o retorno à corporação dos militares expulsos das Forças Armadas a partir de 1964.55

Também a oposição era heterogênea em relação à anistia. Havia quem, logo após o golpe, desse prioridade absoluta ao restabelecimento da ordem legal no país, indicando a anistia como precondição para isso. Tristão de Ataíde, pensador católico, não questionava a natureza da derrubada do governo de João Goulart ao defender simplesmente a anistia para seus integrantes. Tratava-se de devolver-lhes o direito de defesa, principalmente contra acusações de corrupção. Acreditando na existência de um "humanismo brasileiro" a ser preservado das tendências "neofascistas" liberadas pelo golpe, escreveu em 1965:

Se quisermos que o Brasil continue, ou volte, a ser uma terra de convivência harmoniosa, de legalidade sincera, de vida livre, de respeito à dignidade humana, de vida baseada na "ordem" e no "progresso", sem conotações filosóficas, mas no sentido profundo desses dois termos, não podemos ser contra a anistia. ${ }^{56}$

Para o Partido Comunista Brasileiro (PCB) a anistia era um importante meio de luta contra a "ditadura militar-fascista" e o restabelecimento das liberdades democráticas no país. Defendia a medida com caráter amplo, geral e irrestrito, pretendendo que fosse um "golpe profundo na repressão", que ampliaria substancialmente "o espaço de movimentação das diversas correntes políticas que lutam contra a ditadura”. Além disso, a anistia constituía uma condição para o surgimento de novos partidos, a legalização do PCB e a instalação de uma Assembléia Nacional Constituinte que definiria o regime político a substituir a ditadura. ${ }^{57}$

No âmbito do Comitê Brasileiro pela Anistia (CBA), duas posições, pelo menos, se diferençavam quanto ao caráter desejável da medida. $\mathrm{O}$ general Peri Bevilaqua, dissidente de primeira hora do regime militar, mi- 
nistro cassado do Superior Tribunal Militar e um dos fundadores da entidade, defendia desde 1965, pelo menos, a concessão de anistia para restabelecer a "unidade moral do povo brasileiro". Ela beneficiaria, também, os "próprios revolucionários responsáveis por crimes contra a Constituição e as leis do país", cuja culpa seria esquecida em prol de um "interesse social muito maior". ${ }^{58}$ Nos núcleos do CBA, no país como no exterior, a defesa desta "anistia recíproca" causava problemas. ${ }^{59}$ Embora o fato de que os torturadores e demais responsáveis por crimes do Estado contra a oposição ainda não tivessem sido julgados e, portanto, não poderiam ser anistiados, permitisse manter a união do movimento, a bandeira da anistia ampla geral e irrestrita é que permitia a sua progressiva ampliação junto à sociedade.

Críticos de anistias de caráter recíproco têm enfatizado as suas conseqüências deletérias para a vida política de um país. Comentando o episódio da detenção do general Augusto Pinochet na Inglaterra, a pedido de um representante do judiciário da Espanha que o responsabiliza pelo assassinato de cidadãos deste país durante o regime ditatorial que comandou no Chile, um jornalista observou: "A detenção também desafia a crença latino-americana de que a melhor forma de construir uma nova democracia é perdoar as antigas violações aos direitos humanos". ${ }^{60}$ Para concluir, diante da grande mobilização de setores da sociedade e do governo chilenos pela libertação do ex-ditador, "que, quando uma sociedade ignora um legado como o deixado por Pinochet com a intenção de seguir em frente, ele pode reaparecer na metade do caminho e se transformar em um grande obstáculo".

O principal obstáculo, neste caso, parece estar na prevalência da perspectiva de negação do caráter irremediavelmente antagônico dos interesses subjacentes aos atos motivadores da anistia. Mesmo críticos severos da anistia recíproca deixam de considerar este aspecto da questão. Durante as comemorações dos vintes anos da lei de 1979, uma jornalista escreveu:

Mesmo possuindo uma Secretaria Nacional de Direitos Humanos, mesmo tendo aprovado uma lei que tipifica o crime de tortura, mesmo possuindo um Programa Nacional de Direitos Humanos, mesmo tendo aprovado uma lei de indenização aos familiares de mortos e desaparecidos políticos, $o \mathrm{Bra}$ - 
sil não consegue encarar o seu passado, admitir os seus erros e adequar as práticas dos órgãos de segurança à realidade democrática. Pois a bandeira do revanchismo é sempre levantada e a Lei de Anistia sempre lembrada pelos integrantes dos órgãos de segurança que atuaram na ditadura militar. É preciso compreender que após vinte anos da anistia a luta pela verdade não está relacionada com punição. Os cidadãos brasileiros não estão atrás dos culpados, não querem a punição dos crimes da ditadura. A própria Lei de Anistia impede isto. Querem apenas o direito de exercer o controle público sobre as práticas dos órgãos de segurança, que nos dias de hoje devem estar guiadas pelos princípios democráticos dentro do Estado de Direito". ${ }^{61}$

A tese de que os problemas do passado são um patrimônio usufruído igualitariamente pelos brasileiros, presente na idéia de que "o Brasil não consegue encarar o seu passado, admitir os seus erros”, contribui para a mistificação do processo histórico. As contribuições dos brasileiros - e não de uma entidade metafísica "Brasil” — para os "erros" relacionados à anistia foram desiguais na proporção e segundo a direção de suas ações políticas concretas. Houve os que depuseram um governo e os que perderam o poder. Houve os que mataram e os que morreram, os que torturaram e os que sofreram com isso.

Compreender que "a anistia, se remete os crimes para o esquecimento, não tem o dom de apagar o passado"62 é um passo à frente no sentido de uma visão crítica do problema. Passo que, no entanto, volta atrás quando acompanhado da tese pela qual a assunção, por parte das Forças Armadas brasileiras, de que alguns de seus membros cometeram "abusos e excessos" durante o regime militar "será um reencontro com a verdade, a melhor forma de deixar o passado definitivamente para trás". ${ }^{63}$

No plano político, o ato de esquecer costuma apresentar altos custos para as vítimas dos atos anistiados. Antônio Negri ${ }^{64}$ chama a atenção para a natureza política da relação entre memória e justiça, se "tomadas num momento singular e consideradas do ponto de vista da subjetividade dos atores". Memória política e justiça política estão em luta e o que é "justo na ação de uma parte torna-se injusto na memória da outra parte; e a memória de uma parte anula a justiça da ação da outra”, isto é, a vitória de uma parte implica "um cancelamento de memória para os vencidos". O elogio do esquecimento em face da derrota, ${ }^{65}$ parcial ou total, é o consen- 
timento ao vencedor para determinar a memória e a justiça. Negri denuncia a ambição totalitária da vontade do vencedor: ter efeitos totais e instalar-se no "âmago da história". O esquecimento, pode-se concluir, seria a vitória do

totalitarismo com "t" minúsculo, daquele pequeno, que, numa sociedade dominada pela velocidade das imagens e da comunicação, faz da relação entre justiça e memória uma vicissitude de interdições, de ostracismos, de exclusões, tão frágeis quanto onipresentes; um enredo de linchagens e falsificações, tão violentas quanto permanentes. ${ }^{66}$

A aceitação da anistia recíproca como uma conveniência da transição controlada e a tese do esquecimento resultam da "pequena e alastrante redução de justiça e memória a 'urgências' do poder", da contaminação pela "droga da falsificação, injetada a cada dia". Negri propõe que se analise a relação entre a justiça do vencedor e a memória dos vencidos, repropondo "o tema das práxis e da responsabilidade no interior de um mundo que, em sua própria estruturação, predetermina os seus sentidos" ${ }^{67}$ Curiosamente, há, entre os vencedores de 1964, quem se considere derrotado no plano da memória. ${ }^{68}$ Para Jarbas Passarinho:

De fato, o nosso lado ganhou a luta armada e perdeu a batalha da comunicação nitidamente. Não teve a menor capacidade de justificar, de explicar, de convencer. Então me ficou essa idéia de que nós, com um pensamento de que não se pode esquecer, nós vamos ter que escrever a história pelos vencidos e somente por eles". ${ }^{69}$

Na verdade, neste caso os militarmente vencedores são apenas pseudovencidos no plano da memória, pelo menos em relação à anistia. ${ }^{70} \mathrm{~A}$ conexão entre a recorrência das medidas de concessão de anistia e os golpes de Estado cai no esquecimento, em benefício daqueles que os preferem como meio de luta política.

No entanto, um importante episódio da conjuntura política em que se formaram as condiçôes para o golpe de 1964 indica a possibilidade de percepção da armadilha do esquecimento. Trata-se da Crise da Legalidade, deflagrada em 1961, quando os ministros militares do presidente renunciante Jânio Quadros tentaram impedir a posse do vice-presidente João 
Goulart, a quem acusavam de tender ao comunismo. A resistência civilmilitar encabeçada por Leonel Brizola, governador do Rio Grande do Sul, barrou a tentativa golpista, que levou o país à beira da guerra civil. $\mathrm{O}$ general Peri Bevilaqua, então no comando da $3^{\underline{a}}$ Divisão de Infantaria (Santa Maria, RS) e primeiro oficial comandante de tropas a pronunciar-se pela solução constitucional, isto é, a posse de Goulart, defendeu a anistia para todos os envolvidos no movimento sedicioso. Contudo, já no comando da 3 a Região Militar, apontou publicamente os ministros militares - marechal Odílio Denys, almirante Sílvio Heck e brigadeiro Grünn Moss - e o deputado Ranieri Mazzilli — presidente interino durante a ausência de Goulart e "amanuense" dos primeiros — como os "golpistas principais do regime". Os crimes por eles cometidos teriam sido "infamantes", fazendo com que merecessem que se lhes amarrassem latas ao rabo, para que se caracterizasse claramente sua atitude contra o Poder Legislativo. ${ }^{71}$ Assim, não cairiam no esquecimento e desfrutariam de menor liberdade de ação.

Os rabos, contudo, ficaram livres de latas e os golpistas, tendo aprendido a lição de 1961, conspiraram silenciosamente e venceram em 1964. Esta lição, o presidente-professor aposentado Fernando Henrique Cardoso parece não ter aprendido. Por isso, em vez de sugerir a Chávez o emprego de latas, ensinou-lhe o truque da anistia. É como se lhe tivesse dito: vamos, dê aos seus rebeldes uma segunda chance. Que eles concretizem amanhã o golpe frustrado de ontem.

\section{Notas}

${ }^{1}$ Barbosa, Rui. Obras completas, vol. XXXII, t. I. Discursos parlamentares, p. 43-44, apud Martins, Roberto Ribeiro, Liberdade para os brasileiros. Anistia ontem e hoje. 2. ed. Rio de Janeiro: Civilização Brasileira, 1978, p. 65.

2 "Anistia", http://cons-costa.vilabol.uol.com.br/Anistia.html

${ }^{3}$ Para uma análise recente, com outro enfoque do tema, ver Porto, Fabíola Brigante Del. A luta pela anistia no regime militar: a constituição da sociedade civil no país e a construção da cidadania. Dissertação de mestrado. Campinas (SP), Universidade Estadual de Campinas, 2002.

${ }^{4} \mathrm{~A}$ anistia aos envolvidos na segunda tentativa, embora proposta por Kubitschek, só se efetivaria em 1961, já no governo de João Goulart.

${ }^{5}$ Ver, a respeito, Martins, Roberto Ribeiro, $O p$. cit 
${ }^{6}$ Conciliação e reforma no Brasil. Um desafio histórico-cultural. 2. ed. Rio de Janeiro: Nova Fronteira, 1982. pp. 87 e 110 . Ver, também, Debrun, Michel. A “conciliação" e outras estratégias. São Paulo: Brasiliense, 1983.

${ }^{7}$ Mayer, Arno J. Dinâmica da contra-revolução na Europa, 1870-1956. Uma estrutura analitica. Rio de Janeiro: Paz e Terra, 1977. p. 58.

${ }^{8}$ Idem. p. 62.

${ }^{9}$ A propósito, ver Nisbet, Robert. Conservantismo. In Bottomore, Tom \& (Orgs.). História da análise sociológica. Rio de Janeiro: Zahar, 1980. pp. 118-165.

${ }^{10}$ Marcuse, Herbert. Idéias sobre uma teoria crítica da sociedade. Rio de Janeiro: Zahar, 1972. p. 116. Para uma apresentação da doutrina contra-revolucionária, de inspiração fascista, crítica porém simpática às suas linhas gerais, ver Brito, Antônio José de. Para a compreensão do pensamento contra-revolucionário: Alfredo Pimenta, António Sardinha, Charles Maurras, Salazar. Lisboa: Hugin Editores, 1996.

${ }^{11}$ Op. cit.p. 14.

${ }^{12}$ Idem. p. 25.

${ }^{13}$ Analisando os processos históricos de enfrentamento entre as classes sociais, Leon Trotsky distingue neles três sentidos: revolução (substituição da classe dominante), anti-revolução (esvaziamento do ímpeto revolucionário) e contra-revolução (destruição das forças revolucionárias). La Revolucion Española. Buenos Aires: El Yunque Editora, 1973. pp. 163-164.

${ }^{14}$ Mayer, Arno J. Op. cit. p. 21.

${ }^{15}$ Idem, p. 77.

${ }^{16}$ Idem, p. 123.

${ }^{17}$ Florestan Fernandes considera contra-revolucionários o golpe militar de 1964 e o regime político dele decorrente: "O que procurava impedir era a transição de uma democracia restrita para uma democracia de participação ampliada, que prometia não uma 'democracia populista' ou uma 'democracia de massas' (...), mas que ameaçava o início da consolidação de um regime democrático-burguês no qual vários setores das classes trabalhadoras (e mesmo das massas populares mais ou menos marginalizadas, no campo e na cidade) contavam com crescente espaço político próprio”. Fernandes, Florestan. Revolução ou contra-revolução? Contexto, São Paulo, n. 5, p. 21, mar. 1978, Grifos do autor.

${ }^{18}$ Jarbas Passarinho, golpista de primeira hora em 1964: "Bom, eu chamei 64 de contrarevolução, e nisso [Jacob] Gorender e eu ficamos de acordo: ele o chamou de contra-revolução preventiva". "Sob o reino do terror", Folha de S. Paulo, 26 de agosto de 1996.

${ }^{19}$ Mayer, Arno J. Op. cit. p. 91. Grifo do autor.

${ }^{20}$ Trotsky, León. La Revolucion Española. Op. cit. p. 159-60. Grifo meu.

${ }^{21}$ A anistia sancionada pelo presidente da República, general João Figueiredo, em 28 de agosto de 1979, teve como resultados imediatos a libertação de quase todos os presos políticos do país e o início do retorno de mais de 5 mil exilados. 
${ }^{22}$ Saes, Décio. A questão da "transição" do regime militar à democracia. In República do capital. Capitalismo e processo político no Brasil. São Paulo: Boitempo Editorial, 2001. pp. 39-40.

23 "Os magnatas da indústria espanhola formam um grupo hostil ao povo, constituindo um dos grupos mais reacionários no bloco, corroído pelas rivalidades internas, dos banqueiros, dos industriais, dos latifundiários, da monarquia, seus generais e funcionários”. Trotsky, León. Op. cit. p. 64.

${ }^{24}$ A bibliografia sobre a transição da ditadura militar para outra forma de dominação política já é vasta. Balanços historiográficos podem ser encontrados em Soares, Gláucio Ary Dillon et al. (Orgs.). A volta aos quartéis. A memória militar sobre a abertura. Rio de Janeiro: Relume-Dumará, 1995. pp. 13-41; Moisés, José Álvaro. Uma crítica da primeira geração de estudos da transição. In . Os brasileiros e a democracia. Bases sócio-politicas da legitimidade democrática. São Paulo: Ática, 1995. p. 23-47, e Selcher, Wayne A. (Org.). A abertura política no Brasil. Dinâmica, dilemas e perspectivas. São Paulo: Editora Convívio, 1988.

${ }^{25}$ Para uma análise que situa a gênese do projeto de abertura política no período governamental anterior, ver Carvalho, Aloísio Henrique Castelo de. O governo Médici e o projeto de distensão política (1969-1973). Dissertação de mestrado. Rio de Janeiro: Instituto Universitário de Pesquisas do Rio de Janeiro, 1989.

${ }^{26}$ Um analista do Serviço Nacional de Informações (SNI) sintetizou com clareza o alcance da anistia para a linha dura: "Desejar a anistia não é contestação; desejá-la, porém, como forma de corrigir as injustiças cometidas pela revolução, já é outra coisa”. Castro, Celso. As apreciações do SNI. In e D’Araújo, Maria Celina (Orgs.). Dossiê Geisel. Rio de Janeiro: Editora da Fundação Getulio Vargas, 2002. p. 47.

${ }^{27}$ A respeito, ver os depoimentos de José Luiz Coelho Neto, João Paulo Moreira Burnier e Enio dos Santos Pinheiro em Soares, Gláucio Ary Dillon et al. (Orgs.). Op. cit. especialmente às páginas 201, 216, 218, 220 e 225-6.

${ }^{28}$ Costa, Raimundo. "Planos de Brizola ameaçaram a anistia", Folha de S. Paulo, 23 de agosto de 1999 .

${ }^{29}$ Passarinho, Jarbas. "Proposta do MDB era mais restrita", Folha de S. Paulo, 24 de agosto de 1999.

${ }^{30}$ Ver, a propósito, Diniz, Eli. O ciclo autoritário: a lógica partidário-eleitoral e a erosão do regime. In: Lima Jr., Olavo Brasil (Org.). O balanço do poder. Formas de dominação e representação. Rio de Janeiro: IUPERJ/Rio Fundo, 1990. pp. 73-86, e Fleischer, David. As desventuras da engenharia política: sistema eleitoral versus sistema partidário. In (Org.). Da distensão à abertura: as eleições de 1982. Brasília: Editora da Universidade de Brasília, 1988. pp. 61-88.

31 “A tradição do autoritarismo", Folha de S. Paulo, 26 de agosto de 1996.

${ }^{32}$ Depoimentos de Jarbas Passarinho e Said Farhat, titular da Secretaria de Comunicação Social do governo João Figueiredo, citados em Trevisan, Cláudia, Zorzan, Patrícia, "Lei da Anistia foi processo de 4 anos", Folha de S. Paulo, 26 de agosto de 1999. 
${ }^{33}$ Luiz Eduardo Greenhalgh, que integrou a direção nacional do CBA, atribuiu a superação do caráter restrito do projeto oficial à pressão popular: "A única luta que a esquerda ganhou durante o regime militar foi a anistia, conquistada dentro do próprio regime". Idem.

34 "A criação de uma Comissão de Reconciliação e Verdade (CRV) (...) se configurava como uma solução magistral para uma situação em que, depois que a histórica eleição multirracial de 1994 pôs fim ao apartheid, as exigências de justiça tinham de ser contrabalançadas com a necessidade de evitar provocar uma reação violenta por parte de um setor da comunidade nacional, ainda dividida”. Vallely, Paul. "África do Sul 'socializa' a dor do apartheid”, Folha de S. Paulo, 3 de agosto de 1998.

35 Wolthers, Gabriela, "Para FHC, falta sinceridade aos opositores da reeleição", Folha de S. Paulo, 29 de novembro de 1996.

${ }^{36}$ Folha de S. Paulo, 14 de dezembro de 1999.

${ }^{37}$ Rossi, Clóvis. "Memória e olvido”, Folha de S. Paulo, 29 de novembro de 1998. 38 . "O coronel", Folha de S. Paulo, 19 de maio de 1995.

${ }^{39}$ Soares, Gláucio Ary Dillon e outros (Orgs.), Op. cit. p. 37.

40 “Convém lembrar às novas gerações que os torturadores e matadores de 'subversivos', à época, não atuaram clandestinamente, mas como agentes oficiais do Estado brasileiro. Muitos deles, aliás, foram premiados e promovidos por esses atos de terrorismo estatal; como, por exemplo, os que participaram da famigerada 'Operação Bandeirante', conforme decreto de 23 de abril de 1970, do então governador do Estado de São Paulo". Comparato, Fábio Konder. "Uma questão de honra", Folha de S. Paulo, 18 de junho de 1996.

${ }^{41}$ Folha de S. Paulo, 23 de agosto de 1995.

${ }^{42}$ Gomes, Oswaldo Pereira, "O revanchismo e a lei dos desaparecidos", Folha de S. Paulo, 26 de março de 1998. Grifo meu. O general Ernesto Geisel deveria estar se referindo a militares acometidos de "tentação" semelhante quando, já ex-presidente, justificou o emprego da tortura na obtenção de informações para uso imediato nas operações repressivas. Ver D’Araújo, Maria Celina, Castro, Celso. Ernesto Geisel. 2. ed. Rio de Janeiro: Editora da Fundação Getulio Vargas, 1997. p. 225.

${ }^{43}$ Comparato, Fábio Konder. "Que fizeste de teu irmão?", Folha de S. Paulo, 14 de agosto de 1995 .

${ }^{44}$ Idem.

45 Idem.

${ }^{46}$ Pronunciamento do deputado Gilnei Viana em 4 de setembro de 1995 sobre o projeto de lei 869/95. A rigor, o deputado também igualava a violência do Estado à resistência democrática: "O passado passou, e nós, que fizemos parte dele, queremos enterrá-lo dignamente, para que a Nação possa dizer que é digna daqueles que lutam no passado, seja de um lado, seja de outro (...)". Grifo meu.

${ }^{47} \mathrm{Um}$ distinguido liberal brasileiro tornou-se igualmente destacado defensor do papel dos golpes militares preventivos na defesa das democracias sul-americanas: "É ilusão pensar 
que a opção do Brasil sob Goulart, ou do Chile sob Allende, era entre dois estilos de democracia - a democracia liberal e a social-democracia. Era antes entre dois tipos de autoritarismo: o de direita e o de esquerda. Aquele, encabulado, biodegradável e declarando-se transicional, tendo em vista eventual redemocratização. Este, ideológico, messiânico, considerando-se fadado à vitória pelo determinismo histórico e praticante da violência 'sistêmica' a fim de implantar a ditadura do proletariado (...). Nem sempre é fácil a distinção entre violência 'preventiva' e violência 'sistêmica'. Os partidários de Pinochet argúem, não absurdamente, que seu líder apenas praticou violência preventiva contra uma violência maior e sistêmica, a do marxismo". Campos, Roberto. "A trapalhada dos lordes", Folha de S. Paulo, 6 de dezembro de 1998.

${ }^{48}$ História Militar do Brasil. 3. ed. Rio de Janeiro: Civilização Brasileira, 1979. pp. 401-402. ${ }^{49}$ As informações biográficas que se seguem foram obtidas em Abreu, Alzira Alves de e outros (Coords.). Dicionário Histórico-Biográfico Brasileiro Pós-1930. 2. ed. rev. e atualiz. Rio de Janeiro: Editora da Fundação Getulio Vargas, 2001. Respectivamente, v. 1., pp. 886-887, e v. 5, pp. 6013-6014.

${ }^{50}$ Bastos, Celso Seixas Ribeiro. "Anistia”. Dicionário de Ciências Sociais. 2. ed. Editora da Fundação Getulio Vargas: Rio de Janeiro, 1987. v. 1, p. 51.

${ }^{51}$ Idem.

52 Discurso na sessão de 27 de dezembro de 1914, transcrito em Tribuna parlamentar República. Rio de Janeiro: Casa de Rui Barbosa, 1955. pp. 80-81. Grifos meus.

${ }^{53}$ Cony, Carlos Heitor. Anistia. Revista Civilização Brasileira, Rio de Janeiro, ano I, n. 1, mar. 1965. p. 22.

54 "Há 20 anos, a anistia era um sonho. E, como tal, tinha suas armadilhas. A principal delas é o confronto com a situação concreta do país. Para muitos, a anistia foi algo imperfeito, limitado. (...) A anistia foi mais uma realidade de correlação de forças políticas, o exercício da saída possível num determinado momento histórico". Gabeira, Fernando "Anistia, ainda que imperfeita", Folha de S. Paulo, 28 de agosto de 1999, republicado em Souza, Daniel, Chaves, Gilmar (Orgs.). Nossa paixão era inventar um novo tempo. Rio de Janeiro: Rosa dos Tempos, 1999. pp. 72-73.

55 Stepan, Alfred. Os militares na política. Mudança de padróes no Brasil. Rio de Janeiro: Artenova, 1975, pp. 162-163.

${ }^{56}$ Pela anistia. Tempo Brasileiro, Rio de Janeiro, ano III, n. 7, out. 1965. p. 50. Grifo do autor.

${ }^{57}$ Resolução política do Comitê Central do Partido Comunista Brasileiro, maio de 1979. In Corrêa, Hércules. A classe operária e seu partido. Textos do exílio. Rio de Janeiro: Civilização Brasileira, 1980. pp. 231-247, esp. p. 242.

${ }^{58}$ Carta a Ivan Lins, Rio de Janeiro, 8 de abril de 1969. Arquivo Peri Constant Bevilaqua (Museu Casa de Benjamin Constant). A rigor, apenas os prejudicados pelo regime militar poderiam conceder algum tipo de anistia, como propõe o cartunista Henfil em seu Decreto 110: "Considerando que o ato de Anistia realiza, neste momento, uma aspiração nacio- 
nal, decreta: Art. 1ํㅡ - Estão anistiados todos os assinantes do AI-5, lei 477, lei Falcão e 'pacote de Abril"'. Seguem-se mais 13 artigos e um "parágrafo único". Datado de 28 de fevereiro de 1978, o decreto é assinado pelo "povo brasileiro", Henfil e D. Maria (sua mãe) e, embora o texto publicado não as transcreva, informa: "seguem-se 110 milhões de assinaturas”. Souza, Daniel, Chaves, Gilmar (Orgs.). Op. cit. pp. 81-82.

${ }^{59}$ Gabeira, Fernando. Carta sobre a anistia. 3. ed. Rio de Janeiro: Codecri, 1980. p. 15. ${ }^{60}$ Padget, Tim. "Augusto Pinochet Ugarte", Folha de S. Paulo, 24 de dezembro de 1998. ${ }^{61}$ Tavares, Celma. "Anistia: o Brasil após 20 anos", agosto de 1999, http://www.torturanuncamais .org.br

${ }^{62}$ Rossi, Clóvis. "Falta um "mea culpa”, Folha de S. Paulo, 6 de agosto de 1995.

${ }^{63}$ Idem.

64 "Vestígios de um lugar de liberação", Folha de S. Paulo, 10 de agosto de 1997.

${ }^{65}$ Comentando os aspectos restritivos da lei da anistia, uma crítica observa: "Mais grave, porém, era conter a lei um perdão incondicional aos integrantes do Aparato Repressivo que estiveram envolvidos com a tortura. (...) Ele dificultaria eventuais investigaçôes sobre as atividades do Aparato Repressivo, constituindo portanto uma derrota para a oposição". Alves, Maria Helena Moreira. Estado e oposição no Brasil (1964-1984). Petrópolis: Vozes, 1987. p. 268. Grifo meu.

66 "Vestígios de um lugar de liberação", Folha de S. Paulo, 10 de agosto de 1997.

${ }^{67}$ Idem.

${ }^{68}$ Ver, a propósito, D’Araújo, Maria Celina et al. (Orgs.). Os anos de chumbo. A memória militar sobre a repressão. Rio de Janeiro: Relume-Dumará, 1994. p. 13.

69 "Segredos da história", Folha de S. Paulo, 26 de agosto de 1996.

${ }^{70}$ Para uma discussão interessante da relação entre a anistia de 1979 e a memória, privilegiando outros aspectos, ver Reis, Daniel Aarão. Ditadura militar, esquerdas e sociedade. Rio de Janeiro: Jorge Zahar, 2000. pp. 69-73.

71 "General Peri Bevilaqua acusa e sentencia: amarrem uma lata ao rabo dos golpistas", $A$ Noite, Rio de Janeiro, 1ํ de novembro de 1961.

\section{Resumo}

O artigo discute aspectos da anistia politica promulgada em 1979 no Brasil. Considera suas conexōes com a conjuntura de transição no país, mas propõe que seu significado profundo está relacionado com as tradiçôes de conciliação e contra-revolução da história politica brasileira. 
Anistia e Crise política no Brasil pós-1964 • 313

\section{Abstract}

The article argues aspects of the political amnesty promulgated in 1979 in Brazil. It considers its connections with the transition conjuncture in the country, but it proposes that its profound meaning is related with the traditions of conciliation and counterrevolution in the Brazilian political history. 